\title{
INGENIERÍA AGROECOLÓGICA
}

\begin{tabular}{|c|c|c|}
\hline Estudiante & Proyecto & Asesor \\
\hline Martha Carolina Bello & $\begin{array}{l}\text { Respuesta microbiológica de la } \\
\text { bovinaza, a la inoculación con mi- } \\
\text { croorganísmos eficaces y lombriz } \\
\text { roja californiana (eisenia foetida). }\end{array}$ & Martha Lizzie Rojas \\
\hline Philip Torres & $\begin{array}{l}\text { Evaluación de la efectividad de } \\
\text { dos productos comerciales de } \\
\text { trichoderma harzianum y dos } \\
\text { preparados microbiales, sobre el } \\
\text { desarrollo de patógenos de papa } \\
\text { y lechuga. }\end{array}$ & Omar Guerrero \\
\hline Yamith Cifuentes & $\begin{array}{l}\text { Identificación y evaluación del ni- } \\
\text { vel poblacional de la mosca blan- } \\
\text { ca lanuda aleurothrixus floccossus } \\
\text { (maskell) (hemiptera: aleyrodidae) } \\
\text { en el agroecosistema cafetero del } \\
\text { departamento del Huila. }\end{array}$ & María Teresa Ortiz \\
\hline $\begin{array}{l}\text { Miguel Angel } \\
\text { Ronderos }\end{array}$ & $\begin{array}{l}\text { Determinación de la relación entre } \\
\text { el estado sanitario y la caracteriza- } \\
\text { ción micorrízica de eugenia myrti- } \\
\text { folia, en parques de Bogotá D. C. }\end{array}$ & José Francisco García \\
\hline $\begin{array}{c}\text { Denis Amparo } \\
\text { Palacios }\end{array}$ & $\begin{array}{l}\text { Evaluación ex-post del proyecto } \\
\text { de formación integral de gestores } \\
\text { rurales de las localidades de Ciu- } \\
\text { dad Bolívar y Usme. }\end{array}$ & Astrid Gonzáles \\
\hline $\begin{array}{c}\text { Lermen Timar } \\
\text { Forigua }\end{array}$ & $\begin{array}{l}\text { Estandarización de procedimien- } \\
\text { tos para el monitoreo directo de } \\
\text { plagas en los ornamentales de ex- } \\
\text { portación de la empresa Jardínes } \\
\text { de Chía Ltda. - sede La Balsa. }\end{array}$ & Eliana Orduz \\
\hline Felipe Eslava & $\begin{array}{l}\text { Evaluación técnica de dos fuentes } \\
\text { orgánicas para el proceso de nu- } \\
\text { trición en el cultivo de lechuga. }\end{array}$ & Miguel Benavides \\
\hline Eliana Luyeimi López & $\begin{array}{l}\text { Detección molecular de rosellinia } \\
\text { bunodes (berk \& br.) y rosellinia pepo } \\
\text { pat., en suelo, mediante la utiliza- } \\
\text { ción de iniciadores específicos por } \\
\text { la técnica de PCR (reacción en ca- } \\
\text { dena de la polimerasa). }\end{array}$ & Jorge Evelio Ángel \\
\hline
\end{tabular}

